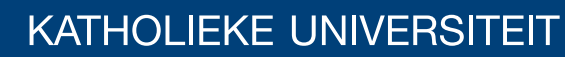 \\ LEUVEN
}

\section{Faculty of Business and Economics}

\section{KH55 ROIRII) RUP DODQG, QRRP DO\& RQWRO HFKDQLP VIRU 6XSSAHU6 HOFIRQRI( [ SHIP HQUEC YGHQFH}

\%DUW IHV QFNI) LIS15 RRGKRRWW

DEPARTMENT OF ACCOUNTANCY, FINANCE AND INSURANCE (AFI) 


\title{
THE ROLE OF FORMAL AND INFORMAL CONTROL MECHANISMS FOR SUPPLIER SELECTION: EXPERIMENTAL EVIDENCE
}

\author{
Bart Dierynck $^{1}$ \\ Katholieke Universiteit Leuven \\ Naamsestraat 69 \\ 3000 Leuven - Belgium \\ E-mail : bart.dierynck@econ.kuleuven.be \\ Filip Roodhooft \\ Katholieke Universiteit Leuven \& \\ Vlerick Leuven Gent Management School \\ Naamsestraat 69 \\ 3000 Leuven - Belgium \\ E-mail: filip.roodhooft@econ.kuleuven.be
}

Working paper

June 2010

${ }^{1}$ Corresponding author.

We gratefully acknowledge the comments on earlier versions of this paper of Henri Dekker, Alexandra Van den Abbeele, Stijn Masschelein, Margareth Christ and Luk Warlop. We also thank participants at the EAA Doctoral Colloquium 2008, the ENROAC Summer School 2008, the New Directions Conference in Management Accounting 2008, the EAA Annual Conference 2009, the AAA Annual Meeting 2009 and the $5^{\text {th }}$ Conference on Performance Measurement and Management Control for their helpful comments and suggestions. Bart Dierynck gratefully acknowledges financial support from the Research Foundation Flanders (FWO). 


\title{
THE ROLE OF FORMAL AND INFORMAL CONTROL MECHANISMS FOR \\ SUPPLIER SELECTION: EXPERIMENTAL EVIDENCE
}

\begin{abstract}
$\underline{\text { Abstract }}$
Previous research in operations has emphasized the importance of internal integration for firm performance. This study shifts the focus to determinants of internal integration and experimentally investigates the role of management control mechanisms for the integration of marketing information about customer preferences in supplier selection decisions. To derive our hypotheses, we draw upon relational framing theory and the distinction between formal and informal control mechanisms. Our experiment manipulates two types of formal control mechanisms and the informal control mechanism so that each control mechanism either evokes a group or an individual frame. With respect to the different combinations of formal control mechanisms, we show that only the combination in which both formal control mechanisms evoke a group frame lead to a high degree of customer-oriented supplier selections. More importantly, we show that the informal control mechanism is driving the degree of customeroriented supplier selections when formal control mechanisms evoke conflicting frames, while the informal control mechanism does not lead to any difference when both formal control mechanisms evoke a group frame. Our results contribute to the literature about internal integration and the management control literature.
\end{abstract}

$\underline{\text { Key words }}$ control mechanisms, supplier selection, customer-orientation, experiment 


\section{INTRODUCTION}

Internal integration, which is the degree to which different functional departments of a firm work together in order to fulfill customer requirements, focuses on the breakdown of functional barriers, the alignment of functional strategies and the development of synchronized and integrated processes (Flynn et al., 2009; Hayes and Wheelwright, 1984; Pagell, 2004). Previous research has provided evidence about the importance of internal integration. Germain and Iyer (2006), for instance, found that internal integration improved financial performance while Flynn et al. (2009) and Zhao et al. (2010) observe that internal integration is a necessary requirement to reap the full benefits of external integration with customers and suppliers. Given the importance of internal integration, a natural question to ask is how internal integration can be improved. There is, however, a paucity of studies about the determinants of internal integration. On the other hand, research remains silent about integration between marketing and purchasing. Integration between marketing, which has knowledge about customer preferences, and purchasing, which selects suppliers, is however important as the preferences of customers, which are the most important assets of firms, should be taken into account when selecting suppliers (Sheth et al., 2009). This study tries to fill these gaps in the literature by experimentally studying the influence of management control mechanisms on the integration of customer-related information in supplier selection decisions.

We rely on relational framing theory to derive our hypotheses. Relational framing theory posits that individuals do not behave in a strictly self-interested manner but contingent on the framing of the social situation (Tetlock and McGraw, 2005). As control mechanisms frame the social situation of a cross-functional interface by creating or removing boundaries between functional departments, the theory is well-suited to make directional hypotheses about the role of 
control mechanisms in the purchasing-marketing interface. Our study also extends relational framing theory by introducing the distinction between formal control mechanisms, which are installed top-down, and the informal control mechanism, which is socially constructed, and making predictions about the importance of informal control mechanism for different types of combinations of formal control mechanisms. More specific, we make a distinction between formal control mechanisms that are congruent with each other (i.e. formal control mechanisms send out the same message) and formal control mechanisms that are not congruent with each other (i.e. formal control mechanisms send out a conflicting message). This distinction is relevant as firms often switch between equilibrium conditions, under which formal control mechanisms are assumed to be congruent, and disequilibrium conditions, under which formal control mechanisms are not necessarily congruent.

The results emphasize the importance of formal and informal control mechanisms for increasing internal integration. We first show show that a high degree of internal integration is only attainable if both formal control mechanisms are congruent. More importantly, we find that the informal control mechanism is the main determinant of internal integration if formal control mechanisms send out conflicting messages, while the informal control mechanism does not lead to any differences when both formal control mechanisms are focused on optimizing the performance of the firm as a whole. Consistent with our theory, we find that subjects in case of conflicting formal control mechanisms consciously rely on the informal control mechanism and that the informal control mechanism reframes the formal control mechanism that is not in line with the message of the informal control mechanism. By explicitly focusing on different combinations of formal control mechanisms, these results shed new insights on the interaction 
between formal and informal control mechanisms and can explain the mixed evidence from prior literature about the importance of formal versus informal control mechanisms.

As we will proxy internal integration by the degree to which information from the marketing department is integrated in supplier selection decisions, we begin by describing the interface between purchasing and marketing. This is followed by an overview of the theoretical background of this study. The third section of this study contains the experimental design. The results are presented in the fourth section. We conclude this paper with a thorough discussion of the results and some suggestions for further research.

\section{THEORY AND HYPOTHESES}

\section{The purchasing-marketing interface}

Although a lot of interfaces have been examined, the purchasing-marketing interface has been largely neglected in the literature (Ivens et al., 2009; Sheth et al., 2009)2 ${ }^{2}$ However, recent evolutions point at the importance of a close integration between purchasing and marketing (Zhao et al. 2010). First, supply-driven supply chains have been evolved into demand-driven supply chains that take the customer preferences as starting point for supply chain optimizations (Heikkilä, 2002; Jüttner et al., 2007). Marketing departments fulfill an important role in demanddriven supply chains as they have a lot of information about customer preferences and knowledge about how to enhance customer satisfaction and customer loyalty (Moorman and

\footnotetext{
${ }^{2}$ Previous research has investigated different cross-functional interfaces such as the marketing-manufacturing interface (Kahn and Mentzer, 1996; O'Leary-Kelly and Flores, 2002), the marketing-logistics interface (Ellinger, 2000), the marketing-R\&D interface (Maltz et al., 2001) and the purchasing-manufacturing interface (Pagell and Krause, 2002). Although internal integration refers to the alignment of different functional departments, researchers often focus on the interface between two functional departments because such an approach facilitates the identification of factors that can influence the relationship between internal integration and performance.
} 
Rust, 1999; Verhoef and Leeflang, 2009). Second, firms are focusing on their core competencies and are increasingly relying on externally supplied goods and services (Cox et al., 2005). Given the importance of customer preferences in demand-driven supply chains, purchasers should integrate customer preferences in their supplier selection decisions.

Integrating customer preferences in supplier selections, however, will change the nature of supplier selection decisions. Traditionally, suppliers were selected and evaluated based on the total cost that a supplier caused in the supply chain (Plank and Ferrin, 2002). Companies also developed mathematical tools such as Total Cost of Ownership to better approximate the total cost of a supplier. Requiring that customer preferences are integrated when selecting suppliers implies that suppliers can also generate revenues by delivering components that match with the customer preferences and as such increase customer satisfaction. Put differently, a customeroriented supplier selection is a decision that optimizes the trade-off between the total costs that a supplier causes in the buying firm, which are realized in the upstream part of the supply chain, and the revenues generated by the supplier, which are realized in the downstream part of the supply chain (Wouters et al., 2005). Optimizing the trade-off between upstream costs and downstream revenues, however, is not easy because this trade-off happens in the purchasingmarketing interface which is characterized by an information and operating externality. The existence of externalities is a logic consequence of customer-responsive strategies as pursuing such strategies intensifies interdependencies between functional departments (Bouwens and Abernethy, 2000; Chenhall, 2008).

The origin of the information externality in the purchasing-marketing interface is linked to the fact that marketing has information about customer preferences and the revenue-generating possibilities of suppliers, while the purchasing department needs this information to make 
customer-oriented supplier selections (Zhao et al., 2010). In other words, information about customer preferences should be disseminated to the purchasing department and should also be understandable for employees from the purchasing department so that they can integrate the information about the revenue-generating possibilities with the information about the costs that a supplier causes in a supply chain. The operating externality in the purchasing-marketing interface is caused by the fact that supplier selections influence the performance of the marketing department as externally supplied goods and services influence satisfaction of the end customer, which is an important performance metric of the marketing department (Sheth et al., 2009; Verhoef and Leeflang, 2009). Christie et al. (2003) argue that the presence of an information and an operating externality lead to the maximization of departmental profits, which is suboptimal for the firm as a whole. Put differently, customer-oriented supplier selections, which should be observed in perfectly internally integrated firms, are exceptional in firms where total cost is the priority for purchasing and where information exchange between marketing and purchasing is limited. The crucial question remains therefore to identify solutions that can mitigate the negative consequences of these externalities.

\section{Control mechanisms}

Management control literature argues that the implementation of suitable formal control mechanisms can mitigate the negative consequences of information and operating externalities (Christie et al., 2003; Jensen and Meckling, 1992; Rowe, 2004). Formal control mechanisms include the more visible, objective components of a control system such as incentive systems, information systems and standard operating procedures (Anthony et al., 1989; Langfield-Smith, 2007). Relying on the premises of the management control literature, we argue that the provision of understandable information about customer preferences and revenue-generating possibilities 
to employees from the purchasing department as well as making them responsible for the revenues that the selected suppliers generate, will increase the number of customer-oriented supplier selections. In a similar vein, Zhao et al. (2010) argue that information sharing and coordination mechanisms can increase integration between purchasing and marketing.

The negative consequences of the information externality in the purchasing-marketing interface can be mitigated by the provision of understandable information about the consequences of selecting a particular supplier for the firm's revenues and its customer satisfaction (Jüttner et al., 2007). However, information that is exchanged between different departments is often expressed in a typical functional language and difficult to understand for employees from other functional departments (Rowe et al., 2008). Recent research has shown that monetary quantification of the consequences of a decision provides benefits when the consequences of this decision are dispersed over different functional departments (Wouters and Verdaasdonk, 2002). Monetary quantification of the downstream consequences of a supplier selection implies the calculation of the expected revenues associated with the selection of a particular supplier (Kadous et al., 2005) and facilitates the comparison of the costs and benefits that are associated with different suppliers as it translates the diverse consequences into a single financial unit of measurement (Galbraith, 1973). Wouters et al. (2009), for instance, found that monetary quantification plays an important role for selecting appropriate suppliers during new product development while Rowe et al. (2008) provide field evidence that translating the various consequences of a decision in a common language such as money improves cross-functional decision-making.

The negative consequences of the operating externality in the purchasing-marketing interface can be mitigated by an incentive system that recognizes the influence of a supplier on 
the firm's costs as well as on its revenues (Pagell, 2004). Making purchasers responsible for the revenues that the selected suppliers generate should help them to optimize the trade-off between the total costs and the revenue-generating possibilities of the supplier ${ }^{3}$. However, previous research has found that acquisition price and total costs are the most important elements of incentive systems for purchasing employees (Anderson and Chambers, 1985; Dumond, 1994). Aggregate performance measures such as firm profit can instigate an optimal trade-off between the costs and revenues of a supplier as previous research has shown that aggregate performance measure increase firm value when interdependencies between functional departments and business units increase or when they have to pursue a common goal such as customer satisfaction (Bushman et al., 1995; Van der Meer-Kooistra and Scapens, 2009) ${ }^{4}$.

\section{Relational framing theory}

The theoretical predictions about the effect of different combinations of formal control mechanisms on the degree of customer-oriented supplier selections will be grounded in relational framing theory (Tetlock and McGraw, 2005). Relational framing theory posits that individuals do not behave in a strictly self-interested manner but contingent on the framing of the social situation (Messick, 1999). While boundaries between individuals evoke an individual frame and competitive, self-interested behavior, the absence of boundaries stirs up a group frame and cooperative, group-interested behavior. Relational framing theory can be used to derive

\footnotetext{
${ }^{3}$ Although employees from the purchasing department cannot directly control the firm's revenues, Lambert (2001) and Holmstrom (1979) argue that performance metrics are informative for rewarding purposes if the actions of the agent influence the probability distribution of the performance metric. Merchant and Otley (2007) also propose to incorporate performance metrics that the agent can influence without directly controlling them. As selecting a supplier can influence the firm's revenues and profits, integrating these measures in reward systems for purchasers can thus be valuable.

${ }^{4}$ Aggregate performance measures are measured at an organizational level higher than the employee's department level. Local or departmental performance measures are the logical counterpart of aggregate performance measures (Bushman et al., 1995).
} 
hypotheses about the role of control mechanisms in the purchasing-marketing interface because control mechanisms create or remove boundaries between functional departments (Briers and Chua, 2001; Rowe, 2004).

Based on relational framing theory and the characteristics of the control mechanisms described earlier, we posit that monetary quantified information about the downstream consequences of suppliers and a reward system that relies on aggregate performance measures will evoke a group frame and cooperative behavior. On the other hand, information about the downstream consequences of suppliers in a typical marketing language and a reward system that relies on local performance measures will evoke an individual frame and competitive behavior. The presence of two formal control mechanisms to mitigate the negative consequences of the externalities in the purchasing-marketing interface results in four combinations of formal control mechanisms: one combination in which both control mechanisms evoke an individual frame, one combination in which both control mechanisms evoke a group frame and two combinations in which one control mechanism evokes a group frame while the other control mechanism evokes an individual frame.

Psychological and accounting research have already examined the problem of mixed frames and have shown that a conflict between the individual and the group frame will lead to the dominance of the individual frame (Fiske and Taylor, 1991; Gaertner et a., 2002; Rowe, 2004). In other words, if formal control mechanisms send out mixed cues about the situation, individuals will rely on the individual frame to make decisions. As a result, incongruent formal control mechanisms will lead to supplier selections that optimize the performance of the purchasing department, but harms the performance of the company as a whole. 
Relying on the above theory, we expect that only the combination of monetary quantified information and aggregate performance measures will result in a high degree of customeroriented supplier selections. In the three other combinations of formal control mechanisms, people will rely on the individual frame which will result in a low degree of customer-oriented supplier selections.

Hypothesis 1 Combinations of formal control mechanisms that both evoke a group frame will lead to a higher degree of customer-oriented supplier selections than combinations of formal control mechanisms that both evoke an individual frame or combinations of formal control mechanisms that evoke a mixed frame.

Relational framing theory provides us with a strong expectation regarding people's behavior by arguing that the individual frame will dominate if mixed frames are evoked. Turner et al. (1994), however, argue that the way people perceive themselves and make their decisions is also socially constructed. Consistent with this reasoning, Messick (1999) contends that people's interpretation of a situation is not only influenced by the underlying economic structure, which is created by the formal control mechanisms, but also by the larger context in which the economic structure is embedded. Although these statements do not reject the dominance of the individual frame, they imply that the strength of the dominance of the individual frame is determined by the social context, which is neglected in relational framing theory until now.

Management control theory also emphasizes the importance of the social context and considers the social context as an informal control mechanism, which can be described as the combination of informal socialization mechanisms that take place in an organization and that 
facilitate shared values, beliefs and understandings among organizational members (Govindarajan and Fisher, 1980; Ouchi, 1980; Turner and Makhija, 2006). In general, one can make a distinction between an informal control mechanism that promotes integration between functional departments to fulfill customer needs and an informal control mechanism that does not stimulate integration between different functional departments (Homburg et al., 2007; Maltz et al., 2001). While the first type of informal control installs a common identity between members from different functional departments so that employees from other functional departments are considered as members from the own group, the second type of informal control leads to the development of a different identity for different functional departments such that employees from other functional departments are considered as members from another group. Empirical research has already shown that the informal control mechanism influences decisionmaking, frames behavior and outcomes, mitigates different types of control problems and helps to install a high degree of customer-related responsiviness (Homburg et al., 2007; Sprinkle, 2003; Langfield-Smith, 2007). The influence of the informal control mechanism for different combinations of formal control mechanisms (congruent versus not congruent) has, however, not been covered by current research. We will first predict the influence of the informal control mechanism when formal control mechanisms send out conflicting messages.

Our starting point is that people who are confronted with incongruent formal control mechanisms will consciously rely on the informal control mechanism to guide their decisions. In this perspective, psychological research already documented that people consciously look for a more solid base of decision-making in case of ambiguity (Smith and Henry, 1996). This argument is also in line with Ouchi (1980) who argues that the informal control mechanism is the sole form of mediation when formal control mechanisms fail due to ambiguity. 
The conscious reliance on the informal control mechanism in case of incongruent formal control mechanisms will then lead to the reframing of the formal control mechanism that is not in line with the informal control mechanism. With respect to the reframing of incentive systems that are not in line with the informal norms, Turner and Makhija (2006) argue that informal socialization mechanisms inspire high goal congruence and common interests among organizational members. Furthermore, good informal relationships between different functional departments improve insights about how decisions in different functional departments relate to one another which increases the belief of employees that they can influence outcomes together (Wech et al., 1998). Research in economics and social psychology also documents that people have preferences to stick to the social norms at the expense of personal wealth (Eckel and Grossman, 2005). Taken together, an informal control mechanism that promotes cross-functional integration will increase the importance and salience of common goals, while an informal control mechanism that does not stimulate integration between different functional departments strengthens the importance of departmental goals.

Informal control mechanisms also have the ability to reframe information that conveys another message than the social context. Daft and Weick (1984) and Huber (1991), for instance, contend that information is given meaning in accordance with existing organizational understandings. Consistent with this conjecture, White et al. (2003) found that the interpretation of information is influenced by the shared values and beliefs of the social setting. Research in social psychology also emphasizes the importance of the social situation for the interpretation and evaluation of information (Tajfel and Turner, 1986; Turner et al., 1994). Birnbaum et al. (1976), for instance, found that the credibility of the information source influences the use and weight of information for decision-making. Lastly, Turner and Makhija (2006) argue that the 
existence of a common identity between employees from different functional departments stimulates the use of diverse knowledge and helps to develop a common interpretation of the diverse knowledge. In sum, current literature suggests that information about the revenuegenerating possibilities of suppliers will be more easily integrated if the informal control mechanism promotes cross-functional integration.

Relying on the basic premise of relational framing theory and on the hypothesis that the strength of the dominance of the individual frame is socially constructed, we argue that the reframing by the informal control mechanism will weaken the dominance of the individual frame if the informal control mechanism promotes cross-functional integration and strengthen the dominance of the individual frame if the informal control mechanism does not stimulate crossfunctional integration. Consistent with the argument that relational framing theory does not make a distinction between different combinations of incongruent formal control mechanisms, we posit that the influence of the informal control mechanism will be the same for different combinations of incongruent formal control mechanisms. In other words, we expect that the reframing of an incentive system that is not in line with the common understandings between employees will have the same influence on the degree of customer-oriented supplier selections as the reframing of information about the revenue-generating possibilities of suppliers. Our hypothesis is thus as follows:

Hypothesis 2: The decreasing effect of incongruent formal control mechanisms on the degree of customer-oriented supplier selections is weakened when the informal context promotes crossfunctional integration. 
Relational framing theory argues that if both formal control mechanisms evoke the same frame, this frame will drive the behavior of employees. The question arises whether an informal control mechanism that is (not) in line with the message of the formal control mechanisms can strengthen (weaken) the frame of the formal control mechanisms. Contrary to the situation in which the formal control mechanisms evoke a conflicting frame, formal control mechanisms send out a clear message which will eliminate the conscious reliance on the informal control mechanism. However, Lembke and Wilson (1998) argue that relying on the social context to make decisions is also an unconscious process. As a result, we argue that an informal control mechanism that is in line with the message of the formal control mechanism will have an additional effect on the degree of customer-oriented supplier selections due to unconscious relying on the social context. In other words, an informal control mechanism that promotes cross-functional integration will increase the degree of customer-oriented supplier selections if both formal control mechanisms evoke a group frame, while an informal control mechanism that does not promote cross-functional integration will decrease the degree of customer-oriented supplier selections if both formal control mechanisms evoke an individual frame. This expectation is consistent with Bhimani (2003) who shows that consistency between the social identity of employees and the purpose of formal control mechanisms increases implementation success. Hackman (1992) also shows that social norms have an amplification quality as they strengthen the dominant messages communicated by other mechanisms.

Hypothesis 3: The increasing (decreasing) effect on the degree of customer-oriented supplier selections of formal control mechanisms that both evoke a group (individual) frame is strengthened by an informal control mechanism that (does not) promotes cross-functional integration. 
It is important to note that the three hypotheses are rooted in relational framing theory. Hypothesis 1 only considers formal control mechanisms and is a test of the basic premise of relational framing theory. Hypothesis 2 and 3 expands relational framing theory and argue that the role of the informal control mechanism is dependent on the combination of formal control mechanisms. Mixed frames will lead to a conscious reliance on the social context and a dominant influence of the social context on the degree of customer-oriented supplier selections. Congruent frames, on the other hand, will lead to an unconscious reliance on the social context and an additive influence of social context on the degree of customer-oriented supplier selections.

\section{DATA AND METHODS}

We designed a scenario-based experiment in which we manipulated the incentive system (aggregate performance measure versus localized performance measure), the information format of the downstream consequences of suppliers (monetary quantified information versus information in a functional language) and the informal control mechanism (high versus low integration between functional departments) to test our hypotheses. As each variable has two conditions and either evokes an individual or group frame, we have eight experimental conditions. We had three main reasons for using an experiment. First, selecting suppliers is a complex decision that is influenced by a lot of factors. An experiment gives us the possibility to manipulate the constructs of theoretical interest and to keep all other exogenous influences constant. Second, congruence between formal control mechanisms is an important aspect of our study. By using an experiment, we can create situations in which formal control mechanisms are congruent or not. Third, studies about relational framing theory often use experiments (Rowe, 
2004; Tetlock \& McGraw, 2005). As we want to extend relational framing theory, an experiment is the most suitable research method.

\section{Subjects}

367 undergraduate students (average age: 20.5 years) of a large West-European university participated in the experiment. All participants have followed courses in operations management, marketing and management accounting and are familiar with concepts such as supplier selection, total cost of ownership, customer satisfaction and customer value. Participants received a course credit and they could win film tickets. They were informed that that the probability of winning a film ticket increased with increasing performance on the experimental task. The film tickets were assigned to the four best performing subjects of each condition (MacIntyre and Ryans, 1983).

\section{Procedure}

The experiment was programmed in Authorware so that subjects could make their decisions on computer. Subjects were randomly assigned to one of the eight experimental conditions ${ }^{5}$. The experiment consists of three phases. During the first phase of the experiment, subjects read the experimental scenario and were assigned the role of a purchaser of a company that produces and sells parquet floors. Subjects had to select a new supplier of wood because the current supplier has stopped the production of wood for parquet floors. It was further mentioned that wood is a key component for parquet floors and, as such, an important determinant of customer satisfaction. The scenario further explained the incentive system, the meaning of the information about the revenue-generating possibilities of suppliers and the informal control mechanism. At

\footnotetext{
${ }^{5}$ Males ( $\mathrm{n}=233$ ) and females $(\mathrm{n}=134)$ are equally divided over the experimental conditions so that our results cannot be biased by gender effects. Furthermore, there are no differences between experimental conditions with respect to age $(\mathrm{F}=0.36, \mathrm{p}>0.90)$, motivation $(\mathrm{F}=1.68, \mathrm{p}>0.10)$, preference for film tickets $(\mathrm{F}=0.69, \mathrm{p}>0.68)$ and grades from previous years $(\mathrm{F}=0.85, \mathrm{p}>0.54)$.
} 
the end of the experimental scenario, we clearly explained how subjects can earn points that will be used to assign film tickets. The experimental scenario was dispersed over different screens and subjects could read each screen as long as they want, but they cannot go back to earlier screens.

During the second phase of the experiment, subjects had to make six supplier selections ${ }^{6}$. They had to make a choice between two suppliers and received total cost information and information about the revenue-generating possibilities for each supplier ${ }^{7}$. Subjects in the different conditions received the same total cost information, which was given by one number, but depending on their condition, they received information about the revenue-generating possibilities either in monetary form or in a typical marketing language. Both manipulations of the information about the revenue-generating possibilities are economically equivalent and should lead to the same supplier choice. Each supplier selection was presented on one screen. Participants could look at each screen as long as they want, but they could not go back. In order to avoid order effects, the sequence of the six supplier selections was randomized.

Subjects had to indicate their purchase intention for one of both new suppliers by moving a slider over a horizontal bar $^{8}$. By doing this, they divided 100 points between the two new

\footnotetext{
${ }^{6}$ The six supplier selections differed from each other with respect to the movements of the total costs towards the current supplier. In two supplier selections, the total cost of both suppliers was higher compared to the total cost of the current supplier, in two supplier selections the total cost of both suppliers was lower compared to the total cost of the current supplier and in two supplier selections the total cost of one supplier was higher while the total cost of the other supplier was lower compared to the current supplier. Within each group of two supplier selections, there was one supplier selection in which the movements of the total cost of both suppliers were in a small range and one supplier selection in which the movements of the total costs were in a large range compared to the total cost of the current supplier. We differed the movements of the total cost to avoid that the results are driven by a particular movement of the total cost. The Cronbach $\alpha$ of the six supplier selections is 0.91 so that we can conclude that the different supplier selections measure the same construct.

${ }^{7}$ Although we do not give costs for the different components of the total costs, we clearly indicated that purchasing costs, costs of waste, store costs and order and administrative costs are included in the total cost of each supplier.

${ }^{8}$ Marketing research has already shown that purchase intention scales are good predictors of real buying behaviour (Wright and MacRae, 2008).
} 
suppliers. The more points they gave at a supplier, the higher their purchase intention for that supplier. The use of the sliderbar had the advantage that subjects cannot make calculation errors by dividing 100 points between the two suppliers. Subjects were informed that the division of 100 points over the two suppliers will be used to assign film tickets. If one assigned more than 50 points to the correct supplier based on his incentive system, then one earned that number of points. However, if one assigned more than 50 points to the wrong supplier based on his incentive system, then the number of points that is assigned to the wrong supplier was subtracted from the total number of points. If one was indifferent between two suppliers, then one could earn nor loose points. So, only the majority of the points that were assigned to a supplier were taken into account to calculate the total number of points. We linked the external reward to the incentive system because earlier research has shown that incentive systems are the most important driver of purchaser's behavior (Dumond 1994).

The third phase of the experiment was an ex-post questionnaire that consisted of manipulation checks, general questions about perception of the marketing department and the marketing information, questions with respect to emotional feelings towards the marketing department and identification questions. We also asked questions about the strength of the incentive system, information about revenue-generating possibilities and informal control mechanism to create (remove) boundaries between both departments. For the ex-post questions, we used the same sliderbar of 100-points as in the supplier selections. The subjects assigned a high score to questions about motivation to score well on the task (average $=63$, median=62), clarity of the experimental scenario (average $=78$, median=76), entering into the scenario (average $=65$, median $=69$ ) and enjoying oneself with the experimental task (average $=60$, 
median=61). Scores on these questions do also not significantly differ between experimental conditions ( $\mathrm{F}>0.15$ for all tests).

\section{Manipulations}

The incentive system is manipulated by a local or an aggregate performance measure (Bushman et al., 1995; Dumond, 1994; Plank and Ferrin, 2002) (see Appendix 1, Panel A). The local performance measure, which evokes an individual frame, is based on the difference between the total cost of a supplier and $10 \%$ of the revenues that a supplier will generate if that particular supplier is selected. In other words, the local performance measure is largely based on the total cost of a supplier and should motivate subjects to select the supplier that minimizes the total cost of a supplier and, as such, optimizes the performance of the purchasing department. The aggregate performance measure, which evokes a group frame, is based on the difference between the revenues that a supplier will generate if he is selected and the total cost of the supplier. As such, the aggregate performance measure is based on the profit that a supplier can generate and this should motivate subjects to choose a supplier that optimizes the performance of the company as a whole. Subjects that have a(n) local (aggregate) performance measure are informed that the lower (higher) they score on the incentive formula, the better their performance is. Note that the revenues that a supplier can generate, differ between the two suppliers as the wood of a supplier can decrease or increase customer satisfaction which influences the firm's revenues.

The information about the revenue-generating possibilities of a supplier was manipulated by giving this information in a monetary form or by means of rankings (see Appendix 1, Panel B). The monetary quantified information should be easier to understand and evoke a group frame. The rankings should be difficult to understand and this should reflect the difficulties that purchasing employees encounter when they receive information in a typical marketing language. 
The use of rankings is consistent with the idea that marketing managers often have intuitive conceptions about the supplier that is preferred by the customers while they do not know the monetary difference between the two suppliers. Subjects were further informed that the purchased component has three important characteristics (durability, strength and maintenance) that could decrease or increase customer satisfaction. They were further informed that the three characteristics have equal importance and that the revenues are dependent on customer satisfaction. The monetary quantified information indicates the revenues that the firm will generate if a particular supplier is chosen. For instance, if they choose for supplier A (B) then the firm's revenues will increase with 7200 EUR (1 800 EUR). The rankings indicate the relative position of a supplier for each of the three characteristics of the component. Each supplier has a ranking (one, two or three) for each of the three characteristics and the rankings are constructed in such a way that the supplier that generates the largest revenues has a better ranking than the other supplier in two out of three characteristics. As such, the monetary quantified information and the rankings are economically equivalent. In both conditions, subjects receive the current firm revenues ${ }^{9}$.

The informal control mechanism is manipulated by a scenario and is based on the framework of Rousseau (1990) (see Appendix 1, Panel C). Rousseau (1990) argues that the informal context in an organization has five determinants: material artefacts (i.e. the physical manifestations of the informal context), patterns of activity (i.e. decision-making, coordination and communication mechanisms), behavioral norms (i.e. beliefs of employees regarding acceptable and unacceptable behavior), values (i.e. priorities assigned to certain states or

\footnotetext{
${ }^{9}$ The current supplier is also mentioned in the rankings. However, subjects are told that the current supplier no longer produces the component and that one of both new suppliers has to be chosen.
} 
outcomes) and fundamental assumptions. In the condition with high (low) integration between purchasing and marketing, we manipulated the five elements towards high (low) integration. All other elements of the scenario are the same for both conditions.

\section{Dependent variable}

The purchase intention for both new suppliers is used to construct the dependent variable. We constructed a scale from zero to 100 where zero indicates a preference for the supplier that optimizes the performance of the purchasing department (i.e. supplier that causes the lowest cost) and 100 indicates a preference for the supplier that optimizes the performance of the firm as a whole (i.e. supplier that generates the highest profit). In other words, the higher the score for our dependent variable, the more the subjects integrate the revenue-generating possibilities of a supplier in their decision. For our statistical tests, we take for each subject the average score of the six supplier selections. We will call our dependent variable the degree of customer-oriented supplier selections.

\section{RESULTS}

\section{Manipulation checks and descriptive statistics}

To ensure that the experimental manipulations provided appropriate contrasts between different levels of incentives, information and informal control, we compared answers of the subjects on the manipulation checks. Results from t-tests indicated that the means of questions about the importance of cost in the incentive system, the easiness to integrate information about the revenue-generating possibilities and the informal relations between marketing and purchasing were significantly different in the predicted direction $(\mathrm{p}<0.0001$ for the three $\mathrm{t}$-tests). These results provide evidence for the different frames (individual versus group) that the treatments evoke. Panel A of Table 1 displays the means and standard deviations for the degree of 
customer-oriented supplier selections as well as the number of subjects for each experimental condition. At first blush, the means reflect the patterns that we expect. For both informal contexts, we find that the combination in which both formal control mechanisms evoke a group frame leads to the highest degree of customer-oriented supplier selections.

\section{Insert Table 1 about here}

\section{Hypothesis tests}

Consistent with relational framing theory, Hypothesis 1 predicts that only the combination in which both formal control mechanisms evoke a group frame will lead to a high degree of customer-oriented supplier selections. As Hypothesis 1 only considers formal control mechanisms, we should find the predicted ordinal interaction for both levels of informal control. The significant interaction term between incentive system and information type for high crossfunctional integration $(\mathrm{F}=10.53, \mathrm{p}<0.01)$ and for low cross-functional integration $(\mathrm{F}=41.94$, $\mathrm{p}<0.001$ ) supports the prediction derived from relational framing theory (see Panel B and C of Table 1). Untabulated contrast analyses further confirm the significance of the predicted ordinal interaction $(\mathrm{F}=72.72, \mathrm{p}<0.001$ for high cross-functional integration and $\mathrm{F}=138.50, \mathrm{p}<0.001$ for low cross-functional integration $)^{10}$. We also find that the differences between combinations that contain at least one formal control mechanism that evokes an individual frame are not significant $(\mathrm{F}=1.85, \mathrm{p}>0.15$ for high cross-functional integration and $\mathrm{F}=0.23, \mathrm{p}>0.70$ for low cross-

\footnotetext{
${ }^{10}$ In line with the predicted pattern for Hypothesis 1 , we use the following contrast coefficients: -1 for the cell with a locallocal performance measure and rankings, - 1 for the cell with a local performance measure and monetary quantified information, -1 for the cell with an aggregate performance measure and rankings and 3 for the cell with an aggregate performance measure and monetary quantified information.
} 
functional integration). Finally, the differences between the combinations of formal control mechanisms that evoke conflicting frames are also not statistically significant $(t=0.59, \mathrm{p}>0.50$ for high cross-functional integration and $\mathrm{t}=0.50, \mathrm{p}>0.60$ for low cross-functional integration). This result indicates that incongruence between formal control mechanisms in itself and not a particular type of incongruence leads to a significant decrease in the degree of customer-oriented supplier selections. Although this result is in line with relational framing theory, it is in contradiction with traditional purchasing research, which argues that purchasing employees always will follow their incentive system (Dumond, 1994).

Hypothesis 2 only considers the combinations of formal control mechanisms that evoke conflicting frames and argues that the social context in which these combinations are embedded influences the strength of the dominance of the individual frame. Consistent with Hypothesis 2, we find a significant main effect in the predicted direction for informal control ( $\mathrm{F}=16.16$, $\mathrm{p}<0.001)$, no effect for type of incongruence $(\mathrm{F}=0.59, \mathrm{p}>0.4)$ and no interaction effect between informal control and type of incongruence $(\mathrm{F}=0.00, \mathrm{p}>0.95)$ (see Panel A, B and $\mathrm{C}$ of Table 2). This result implies that an informal context that promotes cross-functional integration limits the decrease in the degree of customer-oriented supplier selections caused by the conflicting frames of the formal control mechanisms. This finding also supports the argument that the informal control mechanism has an influence on the incongruence in itself, rather than on a particular type of incongruence.

Insert Table 2 about here 
The underlying reasoning for Hypothesis 2 states that people experiencing conflicting frames will consciously rely on the informal context. In order to detect whether conflicting frames will lead to a conscious reliance on the informal context, we compare the total response time for the six supplier selections between congruent and incongruent conditions. As Smith and Henry (1996) found that the perception of conflict increases response time, we expect that subjects in incongruent conditions need more time to make a choice between the two suppliers than subjects in the congruent conditions. The increase in response time is caused by the fact that subjects in the incongruent conditions first should perceive the conflict and then have to consult the social context for guiding their decision. An analysis of the response times confirms our expectation. We find that subjects in incongruent conditions need on average $8.8 \%$ more time to make a supplier choice than subjects in the congruent conditions. The difference in response time between congruent and incongruent conditions is statistically significant $(t=-1.83, p<.10)$.

We also argue that the conscious reliance on the informal control mechanism will reframe both formal control mechanisms. Based on ex-post questions about the importance of cost versus profit in the supplier selection and with respect to the reliability of the data about the revenue-generating possibilities of suppliers, we find evidence for the proposed reframing. For both incongruent combinations, we observe a higher focus on profits $(t=2.82, \mathrm{p}<0.01$ for the condition with local PM and monetary quantified information; $\mathrm{t}=3.32, \mathrm{p}<0.01$ for the condition with aggregate PM and rankings) and a higher reliability of the data about the revenuegenerating possibilities $(\mathrm{t}=4.15, \mathrm{p}<0.01$ for the condition with local PM and monetary quantified information; $\mathrm{t}=6.20, \mathrm{p}<0.01$ for the condition with aggregate $\mathrm{PM}$ and rankings) in the social context that promotes cross-functional integration (see Panel D, E and F of Table 2). 
In sum, our results confirm that the individual frame dominates if formal control mechanisms evoke conflicting frames, but we also show that the strength of the dominance of the individual frame is determined by the social context. Data about response times, perception of the incentive system and the reliability of the information further support our theoretical reasoning.

The third hypothesis only considers combinations in which both formal control mechanisms evoke the same frame and predicts an additive influence of the informal control mechanism when the informal control mechanism is in line with the frame that the formal control mechanisms evoke. Analysis of the response times confirms our expectation that this additive effect should be the result of the unconscious processing of the social context. However, the results of a two-way ANOVA with the type of congruence (i.e. both formal control mechanisms evoke either a group or individual frame) and alignment between the frame of the formal control mechanisms and the informal control mechanism can only partially support our hypothesis. As expected, we find that formal control mechanisms that evoke a group frame lead to a higher degree of customer-oriented supplier selections than formal control mechanisms that evoke an individual frame $(\mathrm{F}=260.25, \mathrm{p}<0.001)$, but the interaction effect does not reach statistical significance $(\mathrm{F}=2.33, \mathrm{p}>0.10)$ (see Panel A, B and $\mathrm{C}$ of Table 3). Further investigation of this unexpected result reveals that the degree of customer-oriented supplier selections is significantly different in the predicted direction for formal control mechanisms that evoke an individual frame $(\mathrm{F}=4.60, \mathrm{p}<0.05)$. However, we do not observe any significant difference between the conditions in which both formal control mechanisms evoke a group frame $(\mathrm{F}=0.24$, $\mathrm{p}>0.60$ ). The latter result implies that the decreasing influence of an informal context that does not promote cross-functional integration is absent when both formal control mechanisms evoke a 
group frame. In other words, a social context that promotes cross-functional integration is not necessary if both formal control mechanisms are oriented towards optimizing the performance of the firm as a whole.

Insert Table 3 about here

\section{Additional evidence about the role of the informal control mechanism}

In order to further assess the influence of the informal control mechanism, it is interesting to compare the magnitude of the influence of the informal control mechanism for congruent and incongruent combinations of formal control mechanisms. Based on our theoretical argumentation, we expect that the informal control mechanism will have a greater influence for incongruent combinations of formal control mechanisms. A comparison of the degree of customer-oriented supplier selections for congruent and incongruent combinations of formal control mechanisms is consistent with this reasoning: an informal context that promotes crossfunctional integration increases the degree of customer-oriented supplier selections with $41.69 \%$ in case of incongruent formal control mechanisms, while this increase is only $6.75 \%$ for congruent formal control mechanisms. If we only include the combinations in which both formal control mechanisms evoke an individual frame, then a context that promotes cross-functional integration leads to an increase of $27.02 \%$ in the degree of customer-based supplier selections.

In the ex-post questionnaire, we also asked some questions about the affective feelings of the subjects because Kida et al. (2001) find that affective feelings are an important determinant of decision-making behavior. We asked subjects to give a general rating about the marketing department and to indicate whether they would like to work in the organization that is described. 
We find that the informal context is the main driver for the responses on these questions ${ }^{11}$. Subjects in the conditions that have a high cross-functional integration give a higher rating to the marketing department $(\mathrm{F}=101.56, \mathrm{p}<0.001)$ and have a higher preference to work in the organization that is described $(\mathrm{F}=75.78, \mathrm{p}<0.001)$. These results emphasize again the important role of the informal control mechanism.

\section{DISCUSSION}

Extant literature documents an important role for internal integration. Our paper shifts the focus to the role of management control mechanisms in creating integration between different functional departments. Relying on the distinction between formal and informal control mechanisms and on the social psychological theory of relational framing, we find consistent evidence that the frame that formal control mechanisms evoke (i.e. whether they evoke a group or an individual frame) impacts the degree of integration between purchasing and marketing. Interestingly, our results suggest that the informal control mechanism is most important when formal control mechanisms are not congruently designed, while the informal control mechanism does not influence integration when both formal control mechanisms are oriented towards optimizing the performance of the firm as a whole.

\section{Findings and implications}

The results of our first hypothesis confirm the basic premises of relational framing theory in a context of supplier selection. Importantly, we find that incongruence between different formal

\footnotetext{
11 ANOVA-analyses with informal control, information, incentive system and all possible interactions reveal that only the main term of informal control is statistically significant in explaining the subject's answers on both ex-post questions.
} 
control mechanisms drives employees' decisions and that there is no distinction between different types of incongruent combinations of formal control mechanisms. The main implication of this result is that formal control mechanisms cannot be considered in isolation. For instance, installing reward systems based on group performance without adapting the type of information that is exchanged will not lead to an increase in the degree of internal integration. Thus, although information systems decrease the cost of information transmission, companies should ensure that the exchanged information is understandable. Quantifying the consequences of cross-functional decisions in monetary terms seems to be a possible solution to increase the understandability of the exchanged information. Our results also imply that exchanging understandable information without giving monetary incentives to use this information will not lead to the expected increase in internal integration.

The results for our second and third hypothesis shed light on the role of the informal control mechanism for different combinations of formal control mechanisms. For incongruent formal control mechanisms, we find that people consciously rely on the informal control mechanism which leads to a reframing of the formal control mechanism that is not in line with the message of the informal context. Taken together, the informal control mechanism is the main driver of behavior in case of incongruent formal control mechanisms and the decreasing influence of incongruent formal control mechanisms is partially offset by an informal context that promotes cross-functional integration. The positive influence of a social context that promotes cross-functional integration for the combination of formal control mechanisms that exists of an aggregate performance measure and typical marketing information can be attributed to a higher reliability of the marketing information (Turner and Makhija, 2006). People subject to a local performance measure and monetary quantified information, on the other hand, sacrifice 
personal wealth in order to stick to the social norms if they operate in a context that promotes cross-functional integration. This result is in contradiction with traditional purchasing literature which founds that employees from the purchasing department always follow their incentive system (Dumond, 1994). However, the result is in line with an emerging stream of literature which documents that the social context can stimulate the other-regarding preferences of people.

For congruent control mechanisms, we find that the unconscious reliance on the informal context does not lead to any differences in the degree of internal integration if both formal control mechanisms evoke a group frame. This result is important because it suggests that companies can obtain the first-best solution if the different formal control mechanisms are perfectly aligned and oriented towards optimizing firm profit.

\section{Contributions}

This study fits into the recent stream of research that combines theories from social psychology with concepts from the management control literature to investigate issues in operations. Given its interdisciplinary nature, this study adds to several streams of the literature. First, we add to the operations literature about internal integration. While much of the existing research in this area focuses on the consequences of variations in internal integration (Flynn et al., 2009; Zhao et al., 2010), our study shifts the focus to an important determinant of internal integration (i.e. control mechanisms). As we explain variations in internal integration by behavioral factors, our study adds to the emerging literature about behavioral operations (Bendoly et al., 2010). Also our focus on the purchasing-marketing interface tries to fill a gap in the current operations literature

(Sheth et al., 2009). As the focus on outsourcing increases the influence of suppliers on the quality of the supplied goods and services, effective governance of the interface between 
purchasing and marketing promises to be an important determinant of the firm's customer satisfaction and overall performance (Zhao et al., 2010).

This study also adds to the extant literature about management control mechanisms. Previous literature has provided mixed evidence about the importance of formal and informal control mechanisms for governing different types of relationships. Maltz and Kohli (1996), for instance, found that formal controls are more important than the informal control, while Anand et al. (2009) and Cousins et al. (2006) observe that the reverse is true. In addition, extant research often assumes perfect alignment between different formal control mechanisms (Doerr et al., 1996) or considers formal control as one coherent construct. In this study, we seek to paint a more complete picture of the role of formal and informal control mechanisms by investigating the role of the informal control mechanism for different combinations of formal control mechanisms (congruent versus incongruent combinations). Considering combinations of formal control mechanisms instead of assuming formal control as one coherent construct is also consistent with recent views that firms are implementing packages of control mechanisms (Merchant and Van der Stede, 2007). Our results can explain the mixed evidence of earlier studies as one can argue that studies observing an important role for the informal control mechanism are considering situations with incongruent formal control mechanisms, while studies observing no role for the informal control mechanism are considering situations with congruent formal control mechanisms. Therefore, future research should explicitly control for the congruency of formal control mechanisms when analyzing the role of the informal control mechanism. Our results also lend support to the argument that organizations do not need an informal control mechanism to improve integration under equilibrium conditions (under which formal control mechanisms should be perfectly aligned). However, organizations operating in a 
state of disequilibrium largely benefit from an informal context that promotes cross-functional integration. As most organizations are constantly switching between equilibrium and disequilibrium, investments in promoting cross-functional integration are fruitful.

Our study also develops an own theory about judgment and decision-making in an operations context by combining relational framing theory with a factor that is unique for an operations environment. Although the distinction between formal and informal control mechanisms is well-documented in management control and operations literature, previous research about relational framing does not make this distinction. In summary, introducing formal and informal control mechanisms in relational framing theory extends the theory in itself and makes it possible to draw a more complete picture about judgment and decision-making in an operations context.

\section{Limitations and further research}

This study has its limitations, which provide opportunities for further research. First, we only test the role of the informal control mechanism for packages of formal control mechanisms that consist of two formal control mechanisms. As organizations imply more than two formal control mechanisms, our experimental context is a simplification and the question remains open to which extent our results can be generalized to more complex situations. Relying on relational framing theory, which argues that incongruence in itself drives behavior, we hypothesize that the addition of extra formal control will not change the results. However, testing the boundary conditions of a theory is an important task for researchers.

Second, our experimental design does not allow for interaction and exchange of information between purchasing and marketing as we want to focus on the interpretation of the exchanged knowledge and avoid confounding of the results by different revelations of private 
information between experimental conditions. Further research can add the stage in which the marketing department can decide to exchange information about customer preferences.

Third, the link between a supplier and the revenues that he generates was very clear in our experiment. We acknowledge that this is not always the case in reality but it is a unique feature of the experimental research method to test a theory under simplifying assumptions. Further research can investigate how the complexity of the link between a supplier and the revenues that he generates alters the results. 


\section{REFERENCES}

- Anand, G., Ward, P.T., \& Tatikonda, M.V. 2009. Role of Explicit and Tacit Knowledge in Six Sigma Projects: an Empirical Examination of Differential Project Success. Journal of Operations Management. Forthcoming.

- Anderson, P.F., \& Chambers, T.M. 1985. A reward/measurement model of organizational buying behavior. Journal of Marketing, 48: 7-23.

- Anthony, R., Dearden, J., \& Bedford, N.M. 1989. Management control systems ( $6^{\text {th }}$ ed). Homewood, IL: Irwin.

- Bendoly, E., Croson, R., Goncalves, P., \& Schultz, K. 2010. Bodies of Knowledge for Research in Behavioral Operations. Production and Operations Management. Forthcoming.

- Bhimani, A. 2003. A study of the emergence of management accounting system ethos and its influence on perceived system success. Accounting, Organizations and Society, 28: 523-548.

- Birnbaum, M.H., Wong, R., \& Wong, L.K. 1976. Combining information from sources that vary in credibility. Memory and Cognition, 4(3): 330-336.

- Bouwens, J., \& Abernethy, M. 2000. The consequences of customization on management accounting system design. Accounting, Organizations and Society, 25: 221-241.

- Briers, M., \& Chua, W.F. 2001. The role of actor-networks and boundary objects in management accounting change: a field study of an implementation of activity-based costing. Accounting, Organizations and Society, 26: 237-269.

- Bushman, R.M., Indjejikian, R.J., \& Smith, A. 1995. Aggregate performance measures in business unit manager compensation: the role of intrafirm interdependencies. Journal of Accounting Research, 33(Supplement): 101-128.

- Chenhall, R.H. 2008. Accounting for the horizontal organisation: a review essay. Accounting, Organizations and Society, 33(4-5), 217-550.

- Christie, A.A., Joye, M.P., \& Watts, R.L. 2003. Decentralization of the firm: theory and evidence. Journal of Corporate Finance, 9: 3-36.

- Cousins, P.D., Handfield, R.B., Lawson, B., \& Petersen, K.J. 2006. Creating supply chain relational capital: the impact of formal and informal socialization processes. Journal of Operations Management, 24: 851-863.

- Cox, A., Chicksand, D., Ireland, P., \& Davies, T. 2005. Sourcing indirect spend: a survey of current internal and external strategies for non-revenue generating goods and services. Journal of Supply Chain Management, 41: 39-51.

- Daft, R.L., \& Weick, K.E. 1984. Toward a Model of Organizations as Interpretation Systems. Academy of Management Review, 9(2): 284-295.

- Doerr, K.H., Mitchell, T.R., Klastorin, T.D., \& Brown, K.A. 1996. Impact of material flow policies and goals on job outcomes. Journal of Applied Psychology, 81(2): 142-152.

- Dumond, E.J. 1994. Making best use of performance measures and performance. International Journal of Operations and Production Management, 14(9): 16-31.

- Eckel, C.C., \& Grossman, P.J. 2005. Managing diversity by creating team identity. Journal of Economic Behavior \& Organization, 58: 371-392.

- Ellinger, A. 2000. Improving marketing/logistics cross-functional collaboration in the supply chain. Industrial Marketing Management, 29: 85-96.

- Fiske, S.T., \& Taylor, S.E. 1991. Social Cognition, $2^{\text {nd }}$ Edition. New York, NY: McGraw-Hill. 
- Flynn, B., Huo, B., \& Zhao, X. 2009. The impact of supply chain integration on performance: A contingency and configuration approach. Journal of Operations Management 28(1): 58-71.

- Gaertner, L., Sedikides, C. , Vevea, J.L., \& Iuzini, J. 2002. The "I", the "we" and the "when": a meta-analysis of motivational primacy in self-definition. Journal of Personality and Social Psychology, 83: 574-591.

- Galbraith, J.R. 2005. Designing the customer-centric organisation, a guide to strategy, structure and process. San Franciso: Jossey-Bass.

- Germain, R., \& Iyer, K.N.S. 2006. The interaction of internal and downstream integration and its association with performance. Journal of Business Logistics, 27(2): 29-52.

- Govindarajan, V., \& Fisher, J.. 1990. Strategy, control systems and resource sharing: effects on business unit performance. Academy of Management Journal, 33(2): 259-285.

- Hayes, R.H., \& Wheelwright, S.C. 1984. Restoring Our Competitive Advantage. Wiley, New York, NY.

- Hackman, J.R. 1992. Group influences on individuals in organizations. In Dunnette, M.D., \& Hough, L.M. (Eds). Handbook of industrial and organizational psychology, $2^{\text {nd }}$ ed. Consulting Psychologists Press, Palo Alto, CA, 199-267.

- Heikkilä, J. 2002. From supply to demand chain management: efficiency and customer satisfaction. Journal of Operations Management, 20: 747-767.

- Homburg, C., Grozdanovic, M., \& Klarmann, M. 2007. Responsiviness to Customers and Competitors: the Role of Affective and Cognitive Organizational Systems. Journal of Marketing, 71: 18-38.

- Huber, G.P. 1991. Organizational learning: the contributing processes and the literatures. Organization Science, 2(1): 88-115.

- Ivens, B.J., Pardo, C., \& Tunisini, A. 2009. Organizing and integrating marketing and purchasing in business markets: An introduction to the special issue, issues and implications. Industrial Marketing Management, 38: 851-856.

- Jensen, M.C., \& Meckling, W.H. 1992. Specific and general knowledge, and organizational structure. In: Werin, L., \& Wijkander, H. (Eds), Main currents in contract economics. Blackwell, Oxford, UK.

- Jüttner, U., Christopher, M., \& Baker, S. 2007. Demand chain management - integrating marketing and supply chain management. Industrial Marketing Management, 36: 377-392.

- Kahn, K.B., \& Mentzer, J.T. 1998. Marketing's integration with other departments. Journal of Business Research, 42: 53-62.

- Kadous, K., Koonce, L., \& Towry, K.L. 2005. Quantification and persuasion in managerial judgment. Contemporary Accounting Research, 22(3): 643-686.

- Kida, T.E., Moreno, K.K., \& Smith, J.F. 2001. The influence of affect on managers' capital budgeting decision. Contemporary Accounting Research, 18(3): 477-494.

- Langfield-Smith, K. 2007. A review of quantitative research in management control systems and strategy. In Chapman C.S., Hopwood A.G. \& Shields M.D. (Eds). Handbook of Management Accounting Research, Elsevier: 753-783.

- Lembke, S., \& Wilson, M.G. 1998. Putting the "Team" into Teamwork: Alternative Theoretical Contributions for Contemporary Management Practice. Human Relations, 51(7): 927-944.

- MacIntyre, S.H., \& Ryans, A.B. 1983. Task effects on decision quality in travelling salesperson problems. Organizational Behavior and Human Performance, 32: 344-369. 
- Maltz, E., \& Kohli, A.K. 1996. Market Intelligence Dissemination Across Functional Boundaries. Journal of Marketing Research, 33: 47-61.

- Maltz, E., Souder, W.E., \& Kumar, A. 2001. Influencing R\&D/marketing integration and the use of market information by $\mathrm{R} \& \mathrm{D}$ managers: intended and unintended effects of managerial actions. Journal of Business Research, 52: 69-82.

- Merchant, K., \& Van der Stede, W.A. 2007. Management Control Systems: Performance Measurement, Evaluation and Incentives. Prentice Hall.

- Messick, D.M. 1999. Alternative logics for decision-making in social settings. Journal of Economic Behavior \& Organization, 39(1): 11-28.

- Moorman, C., \& Rust, R.T. 1999. The Role of Marketing. Journal of Marketing, 63: 180-197.

- O'Leary-Kelly, S.W., \& Flores, B.E. 2002. The integration of manufacturing and marketing/sales decisions: impact on organizational performance. Journal of Operations

Management, 20: 221-240.

- Ouchi, W.G. 1980. Markets, Bureaucracies and Clans. Administrative Science Quarterly, 25: 129-141.

- Pagell, M. 2004. Understanding the factors that enable and inhibit the integration of operations, purchasing and logistics. Journal of Operations Management, 22: 459-487.

- Pagell, M., \& Krause, D.R. 2002. Strategic consensus in the internal supply chain: exploring the manufacturing-purchasing link. International Journal of Production Research, 40 (13): 3075-3092.

- Plank, R.E., \& Ferrin, B.G. 2002. How manufacturers value purchase offerings. An exploratory study. Industrial Marketing Management, 31: 457-465.

- Rousseau D.M. 1990. Assessing organizational culture: the case for multiple methods. In Schneider B. (Ed.). Organizational climate and culture. San Francisco: Jossey-Bass.

- Rowe, C. 2004. The effect of accounting report structure and team structure on performance in cross-functional teams. The Accounting Review, 79: 1153-1180.

- Rowe, C., Birnberg, J., \& Shields, M.D. 2008. Effects of organisational process change on responsibility accounting and managers'revelations of private knowledge. Accounting, Organizations and Society, 33(2-3): 164-198.

- Sheth, J.N., Sharma, A., \& Iyer, G.R. 2009. Why integrating purchasing with marketing is both inevitable and beneficial. Industrial Marketing Management, 38: 865-871.

- Smith, E.R., \& Henry, S. 1996. An In-group Becomes Part of the Self: Response Time Evidence. Personality and Social Psychology Bulletin, 22(6): 635-642.

- Sprinkle, G. 2003. Perspectives on experimental research in managerial accounting. Accounting, Organizations and Society, 28: 287-318.

- Tajfel, H. \& Turner, J.C. 1986. The social identity theory of intergroup behaviour. In Worchel, S. \& Austin,W. (eds.) Psychology of intergroup relations (pp. 7-24). Chicago: Nelson-Hall.

- Tetlock, P.E., \& McGraw, P.A. 2005. Theoretically framing relational framing. Journal of Consumer Psychology, 15: 35-40.

- Turner, K.L., \& Makhija, M.V. 2006. The role of organizational controls in managing knowledge. Academy of Management Review, 31(1): 197-217.

- Turner, J.C., Oakes, P.J., Haslam, S.A., \& McGarty, C. 1994. Self and Collective: Cognition and Social Context. Personality and Social Psychology Bulletin, 20(5): 454-463.

- van der Meer-Kooistra, J., \& Scapens, R.W. 2008. The governance of lateral relations between and within organisations. Management Accounting Research 19(4): 365-384. 
- Verhoef, P.C., \& Leeflang, P.S.H. 2009. Understanding the Marketing Department's Influence Within the Firm. Journal of Marketing, 73: 14-37.

- Wech, B.A., Mossholder, K.W., Steel, R.P., \& Bennett, N. 1998. Does work group cohesiviness affect individuals' performance and organizational commitment? Small Group Research, 29(4): 472-494.

- White, J.C., Varadarajan, P.R., \& Dacin, P.A. 2003. Market Situation Interpretation and Response: the Role of Cognitive Style, Organizational Culture, and Information Use. Journal of Marketing, 67: 63-79.

- Wouters, M., Anderson, J., \& Wynstra, F. 2005. The adoption of total cost of ownership for sourcing decisions - a structural equations analysis. Accounting, Organizations and Society, 30: 167-191.

- Wouters, M., \& Verdaasdonk, P. 2002. Supporting management decisions with ex ante accounting information. European Management Journal, 20(1): 82-94.

- Wouters, M., Anderson, J.C., Narus, J.A., \& Wynstra, F. 2008. Accountability for cost and performance in sourcing decisions for new product development projects. Journal of Operations Management, 27: 64-77.

- Wright, M., \& MacRae, M. 2007. Bias and variability in purchase intention scales. Journal of the Academy of Marketing Science, 35(4): 617-623.

- Zhao, X., Huo, B., Selen, W., \& Yeung, J.H.Y. 2010. The impact of internal integration and relationship commitment on external integration. Journal of Operations Management, Forthcoming. 
TABLE 1

Results for Hypothesis 1

Panel A shows the average degree of customer-based supplier selections for the eight experimental conditions. The cells also contain (standard deviation) and [number of participants]. Numbers in italic represent the results for the conditions with low cross-functional integration. Panel B and Panel C contain the ANOVA-analyses for high and low cross-functional integration. Panel D presents a graph of the average degree of customer-based supplier selections for high and low cross-functional integration. Numbers in italic represent the result for the low crossfunctional integration condition.

Panel A: Descriptive Statistics

\begin{tabular}{|c|c|c|}
\hline Infor & & \\
\hline $\begin{array}{l}\text { Rankings } \\
\text { (individual frame) }\end{array}$ & $\begin{array}{l}\text { Monetary } \\
\text { quantified }\end{array}$ & Row means \\
\hline
\end{tabular}

\begin{tabular}{|c|c|c|c|c|c|c|c|}
\hline \multirow{2}{*}{\multicolumn{2}{|c|}{$\begin{array}{l}\text { Local PM } \\
\text { (individual frame) }\end{array}$}} & \multicolumn{6}{|c|}{ (group frame) } \\
\hline & & 47.47 & 37.51 & $\begin{array}{c}57.48 \\
(31.66\end{array}$ & $\begin{array}{r}40.95 \\
(3565)\end{array}$ & $\begin{array}{c}52.64 \\
(2789)\end{array}$ & $\begin{array}{c}39.23 \\
(29.34)\end{array}$ \\
\hline \multirow{7}{*}{$\frac{\text { Incentive }}{\underline{\text { System }}}$} & & [44] & [46] & [47] & [46] & [91] & [92] \\
\hline & Aggregate PM & 54.26 & 37.91 & 86.40 & 87.90 & 70.50 & 62.63 \\
\hline & (group frame) & (19.71) & (20.71) & $(15.46)$ & $(13.81)$ & $(23.89)$ & $(30.65)$ \\
\hline & & [46] & {$[46]$} & [47] & {$[45]$} & [93] & [91] \\
\hline & Column means & 50.94 & 37.71 & 71.94 & 64.17 & & \\
\hline & & $(21.2$ & (21.05) & (28.72) & $(35.83)$ & & \\
\hline & & [90] & [92] & [94] & [91] & & \\
\hline
\end{tabular}

Panel B: Anova-analysis high cross-functional integration

$\begin{array}{lccccc} & \underline{\mathrm{SS}} & \underline{\mathrm{Df}} & \underline{\mathrm{MS}} & \underline{\mathrm{F} \text {-stat }} & \frac{\mathrm{p} \text {-value }}{<.0001} \\ \text { Incentive system } & 14656.95 & 1 & 14656.95 & 27.42 & <.0001 \\ \text { Information } & 20422.43 & 1 & 20422.43 & 38.20 & <.0001 \\ \text { Incentive system x Information } & 5628.22 & 1 & 5628.22 & 10.53 & <0.005 \\ \text { Explained } & 40976.14 & 3 & 13658.71 & 25.55 & <.0001 \\ \text { Residual } & 96225.64 & 180 & 534.59 & & \end{array}$

Panel C: Anova-analysis low cross-functional integration

\begin{tabular}{|c|c|c|c|c|c|}
\hline & $\underline{\mathrm{SS}}$ & Df & $\underline{\mathrm{MS}}$ & $\underline{\text { F-stat }}$ & $\mathrm{p}$-value \\
\hline Incentive System & $25 \overline{32} .18$ & $\overline{1}$ & $25 \overline{632} .18$ & $\overline{43.38}$ & $<.0001$ \\
\hline Information & 32656.03 & 1 & 32656.03 & 55.26 & $<.0001$ \\
\hline Incentive System x Information & 24784.02 & 1 & 24784.02 & 41.94 & $<.0001$ \\
\hline Explained & 82169.69 & 3 & 27389.90 & 46.35 & $<.0001$ \\
\hline Residual & 105772.4 & 179 & 590.91 & & \\
\hline
\end{tabular}




\section{Panel D: Graphical Plot of the Average Degree of Customer-Based Supplier Selections}

High Cross-Functional Integration

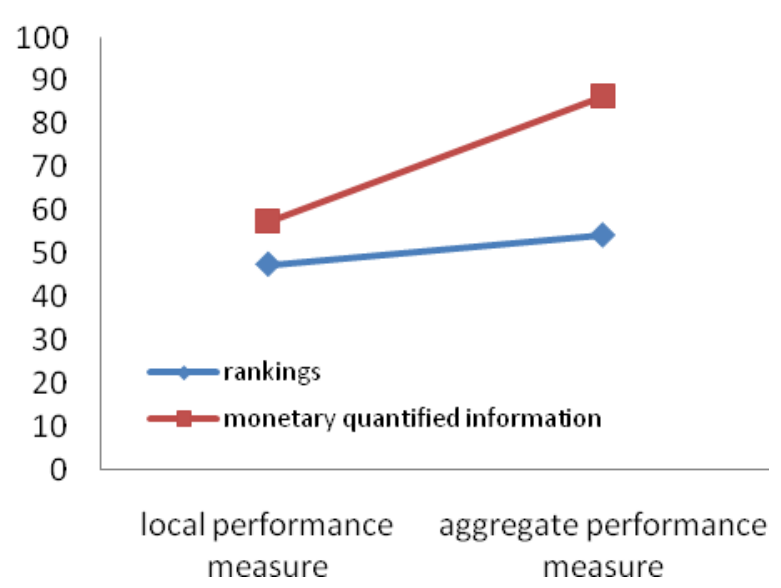

Low Cross-Functional Integration

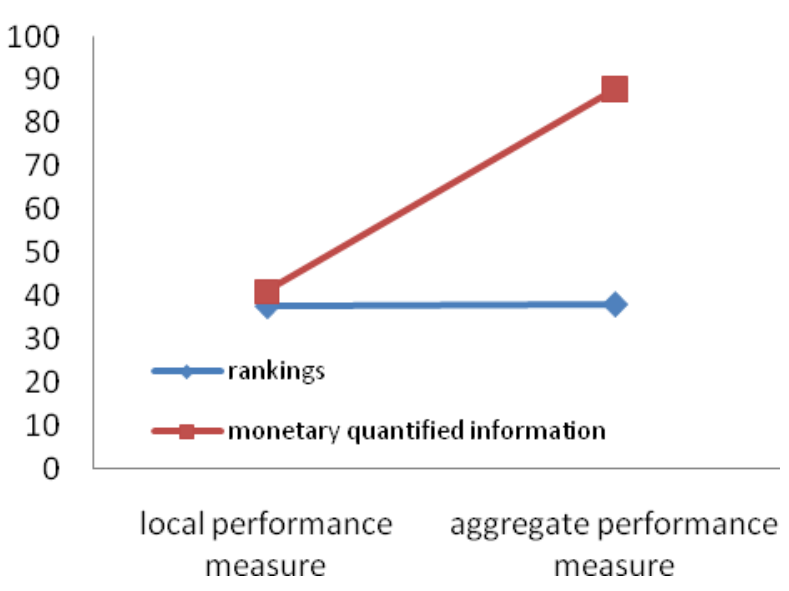


TABLE 2

Results for Hypothesis 2

Panel A shows the average degree of customer-based supplier selections for the experimental conditions in which formal control mechanisms are incongruent. The cells also contain (standard deviation) and [number of participants]. Panel B contains the ANOVA-analysis. Panel C presents a graph of the average degree of customerbased supplier selections. Panel D and Panel E contain statistics for the ex-post questions about the reframing of the formal control mechanisms. Panel F presents a graph of the results for these ex-post questions.

Panel A: Descriptive Statistics Hypothesis 2

\begin{tabular}{|c|c|c|c|c|}
\hline \multirow[b]{3}{*}{ Type of } & & \multicolumn{2}{|c|}{ mation } & \multirow{3}{*}{$\underline{\text { Row means }}$} \\
\hline & & $\begin{array}{l}\text { High cross- } \\
\text { functional } \\
\text { integration }\end{array}$ & $\begin{array}{l}\text { Low cross- } \\
\text { functional } \\
\text { integration }\end{array}$ & \\
\hline & $\begin{array}{l}\text { Local PM + } \\
\text { monetary } \\
\text { quantified } \\
\text { information } \\
\text { (individual frame } \\
+ \text { group frame) }\end{array}$ & $\begin{array}{c}57.48 \\
(31.66) \\
{[47]}\end{array}$ & $\begin{array}{c}40.95 \\
(35.61) \\
{[46]}\end{array}$ & \\
\hline & $\begin{array}{l}\text { Aggregate PM + } \\
\text { rankings } \\
\text { (group frame }+ \\
\text { individual frame) }\end{array}$ & $\begin{array}{c}54.26 \\
(19.71) \\
{[46]}\end{array}$ & $\begin{array}{c}37.91 \\
(20.71) \\
{[46]}\end{array}$ & $\begin{array}{c}46.08 \\
(21.72) \\
{[92]}\end{array}$ \\
\hline & Column means & $\begin{array}{c}55.89 \\
(26.34) \\
{[93]}\end{array}$ & $\begin{array}{c}39.43 \\
(29.01) \\
{[92]}\end{array}$ & \\
\hline
\end{tabular}

Panel B: ANOVA-analysis Hypothesis 2

$\begin{array}{lccccc} & \underline{\mathrm{SS}} & \underline{\mathrm{Df}} & \underline{\mathrm{MS}} & \underline{\mathrm{F} \text {-stat }} & \text { p-value } \\ \text { Informal Control } & 12496.9977 & 1 & 12496.9977 & 16.16 & <.0001 \\ \text { Type of Incongruence } & 454.30992 & 1 & 454.30992 & 0.59 & 0.4444 \\ \begin{array}{l}\text { Informal Control x } \\ \text { Type of Incongruence }\end{array} & 0.35155 & 1 & 0.35155 & 0.00 & 0.9830 \\ \begin{array}{l}\text { Explained } \\ \text { Residual }\end{array} & 12978.8750 & 3 & 4326.2917 & 5.59 & <0.005 \\ & 139961.702 & 181 & & & \end{array}$


Panel C: Graphical Plot of the Average Degree of Customer-Based Supplier Selections

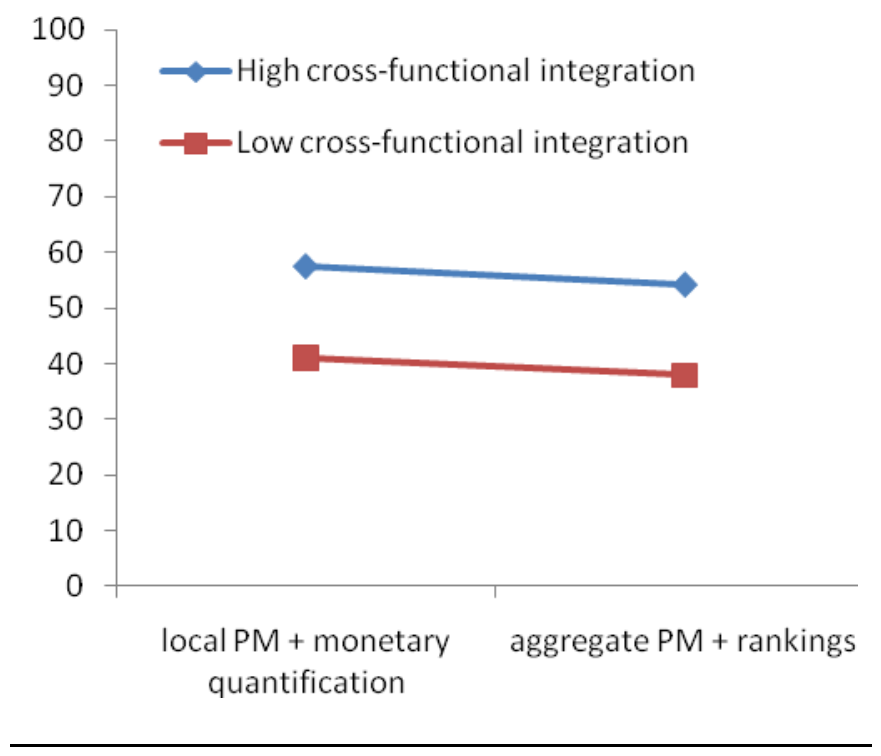

Panel D: Ex-Post Questions for Reframing of the Formal Control Mechanisms (Local Performance Measure and Monetary Quantified Information)

$\begin{array}{cccc}\begin{array}{c}\text { High cross- } \\ \text { functional } \\ \text { integration }\end{array} & \begin{array}{c}\text { Low cross- } \\ \text { functional } \\ \text { integration }\end{array} & \text { t-value } & \text { p-value } \\ 89.14 & 74.39 & 2.82 & \\ 64.22 & 46.43 & 4.15 & <0.01 \\ & & & <0.001\end{array}$

Profit-focus

64.22

4.15

$<0.001$

information

Panel E: Ex-Post Questions for Reframing of the Formal Control Mechanisms (Aggregate performance measure and rankings)

$\begin{array}{cccc}\begin{array}{c}\text { High cross- } \\ \text { functional } \\ \text { integration }\end{array} & \begin{array}{c}\text { Low cross- } \\ \text { functional } \\ \text { integration }\end{array} & \text { t-value } & \text { p-value } \\ 91.7 & 74.22 & 3.32 & \\ 74.76 & 50.17 & 6.20 & <0.005 \\ & & & <0.001\end{array}$

Profit-focus

Reliability of

marketing information
91.7

50.17

6.20

$<0.001$ 
Panel F: Graphical Plots of Ex-Post Questions about Reframing of the Formal Control Mechanisms
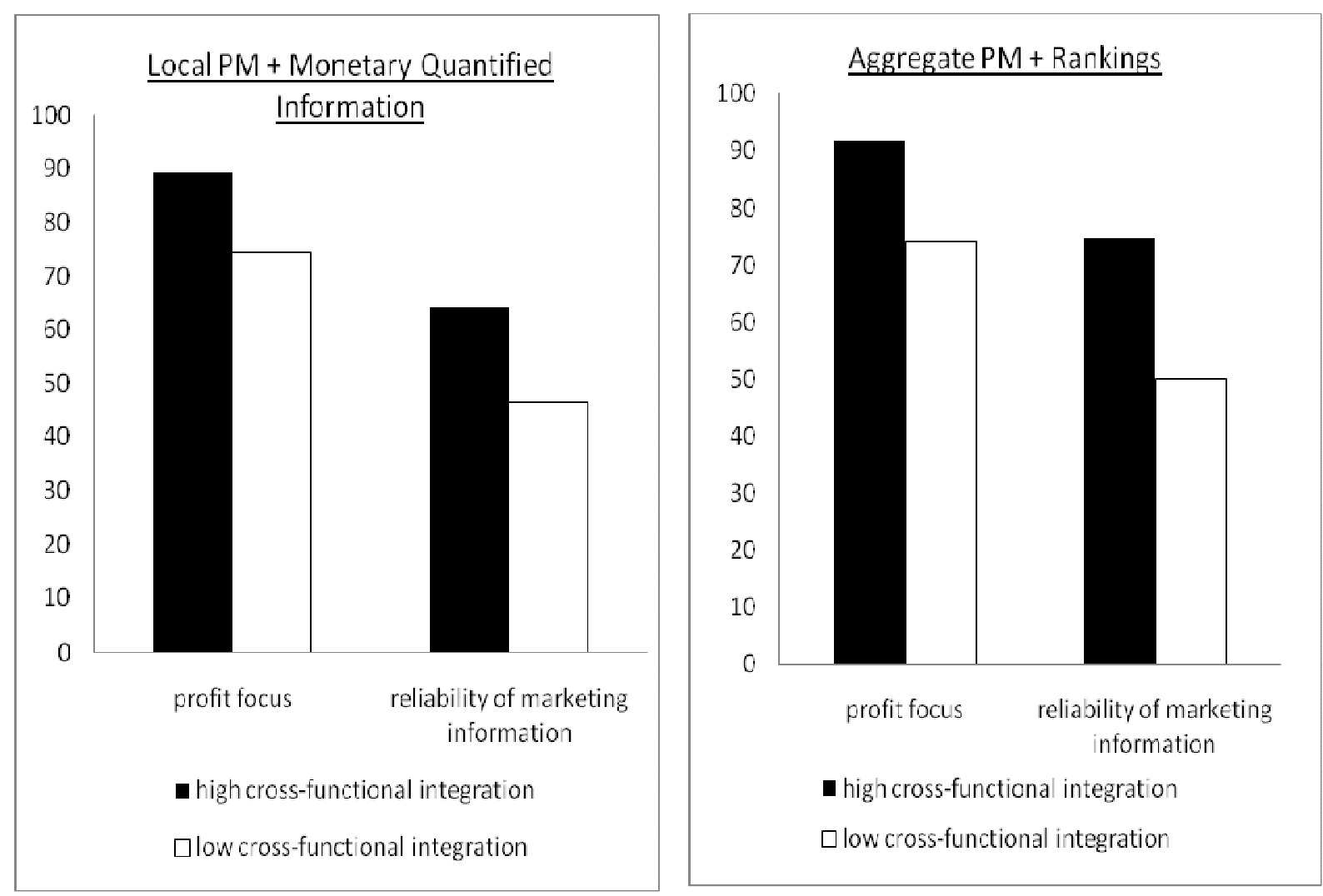
TABLE 3

Results for Hypothesis 3

Panel A shows the average degree of customer-based supplier selections for the experimental conditions in which formal control mechanisms are congruent. The cells also contain (standard deviation) and [number of participants]. Panel B contains the ANOVA-analysis. Panel C presents a graph of the average degree of customer-based supplier selections.

Panel A: Descriptive Statistics Hypothesis 3

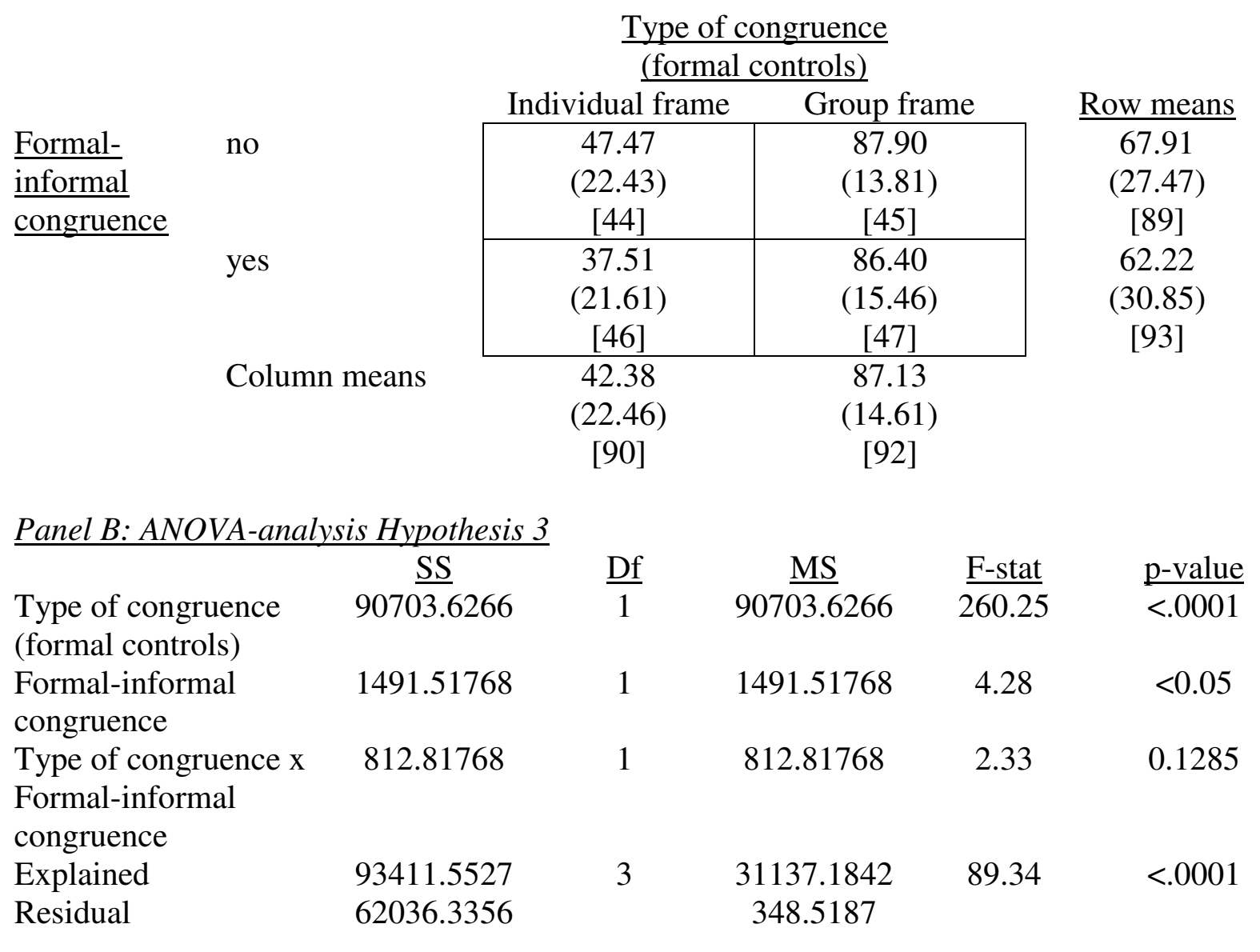


Panel C: Graphical Plot of the Average Degree of Customer-Based Supplier Selections

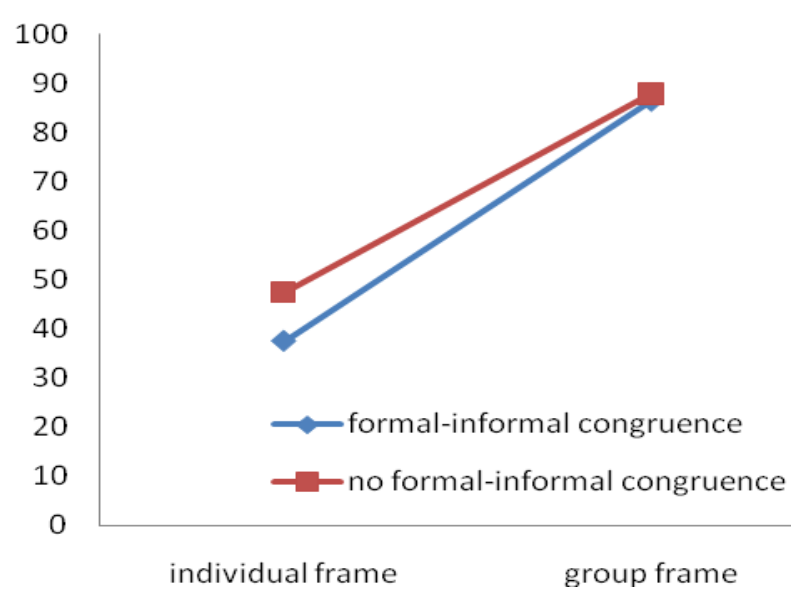




\section{APPENDIX 1}

Panel A: Incentive system

\begin{tabular}{|l|l|l|}
\hline $\begin{array}{l}\text { Local PM } \\
\text { (cost-based })\end{array}$ & $\begin{array}{l}\text { Total cost of the supplier - }(0.1 \times \text { revenues of the } \\
\text { chosen supplier) }\end{array}$ & The lower, the better. \\
\hline $\begin{array}{l}\text { Aggregate } \\
\text { PM } \\
\text { (profit-based) }\end{array}$ & $\begin{array}{l}\text { Revenues of the chosen supplier - total cost of } \\
\text { the selected supplier }\end{array}$ & The higher, the better. \\
\hline
\end{tabular}

Panel B: Information system

\begin{tabular}{|l|l|l|l|l|}
\hline & \multicolumn{3}{|l|}{ Total cost information } & \multicolumn{2}{l|}{ Customer-related information } \\
\hline & Total cost & $\begin{array}{l}\text { Change in total } \\
\text { cost }\end{array}$ & Revenues & Change in revenues \\
\hline Current supplier & 60000 EUR & & 70 000 EUR & \\
\hline New supplier I & 64200 EUR & +4200 EUR & 77 200 EUR & +7200 EUR \\
\hline New supplier II & 61200 EUR & +1200 EUR & 71800 EUR & +1800 EUR \\
\hline
\end{tabular}

${ }^{1}$ Shaded areas are condition specific. In the monetary quantification - condition, subjects receive the information in the shaded areas. In the rankings - condition, subjects receive the customerrelated information as follows:

\begin{tabular}{|l|c|c|c|}
\hline \multicolumn{4}{|c|}{ Customer-based information } \\
\hline & Supplier I & Supplier II & Current supplier \\
\hline Durability & 1 & 2 & 3 \\
\hline Strenght & 1 & 2 & 3 \\
\hline Maintenance & 2 & 1 & 3 \\
\hline
\end{tabular}

Panel C: Informal control

\begin{tabular}{|l|c|l|}
\hline \multicolumn{1}{|c|}{$\begin{array}{c}\text { Low cross-functional } \\
\text { integration }\end{array}$} & Informal element & \multicolumn{1}{c|}{$\begin{array}{c}\text { High cross-functional } \\
\text { integration }\end{array}$} \\
\hline $\begin{array}{l}\text { Purchasing and marketing are } \\
\text { located in a different building. }\end{array}$ & Material artefacts & $\begin{array}{l}\text { Purchasing and marketing are located } \\
\text { in the same building. }\end{array}$ \\
\hline $\begin{array}{l}2 \text { times a year, there is a meeting to } \\
\text { discuss problems. However, } \\
\text { everyone considered the meetings as } \\
\text { boring. }\end{array}$ & $\begin{array}{l}\text { Coordination and } \\
\text { Communication } \\
\text { mechanisms }\end{array}$ & $\begin{array}{l}\text { There is a weekly meeting to discuss } \\
\text { problems and to search for solutions. }\end{array}$ \\
\hline $\begin{array}{l}\text { There are less informal contacts } \\
\text { between the purchasing and } \\
\text { marketing department. }\end{array}$ & Behavioral norms & $\begin{array}{l}\text { There are a lot of informal contacts } \\
\text { between the purchasing and marketing } \\
\text { department. }\end{array}$ \\
\hline $\begin{array}{l}\text { Cross-functional collaboration is not } \\
\text { the most important aspect in your } \\
\text { organization. Everyone is convinced } \\
\text { that a focus on the activities of the } \\
\text { own department will lead to good } \\
\text { results. }\end{array}$ & Values & $\begin{array}{l}\text { Cross-functional collaboration is } \\
\text { considered as fundamental to obtain } \\
\text { good results. }\end{array}$ \\
\hline $\begin{array}{l}\text { Your organization is founded by } 1 \\
\text { man who was convinced that } \\
\text { specialization on the tasks of the } \\
\text { own department is already difficult } \\
\text { enough. }\end{array}$ & Fundamental \\
\hline
\end{tabular}


